\title{
EARLY DEVELOPMENT OF LATE VISTULIAN (WEICHSELIAN) LACUSTRINE SEDIMENTS IN THE ŻABIENIEC SWAMP (CENTRAL POLAND)
}

\author{
DOMINIK PAWLOWSKI \\ Adam Mickiewicz University, Institute of Geology, Maków Polnych 16, 61-606 Poznań, Poland
}

Received 5 May $2011 \quad$ Accepted 11 April 2012

\begin{abstract}
The early sedimentological and ecological developmental stages of a late Vistulian lake in the Żabieniec swamp near Łódź (central Poland) were analysed by radiometric dating, changes in the frequency of specimens and species composition of Cladocera and multivariate statistical analysis (DCA). The longevity of the lake resulted in a fairly complete sedimentary record from approximately $22 \mathrm{ka}$ to $11 \mathrm{ka}$ cal BP. Species composition and the variability in the frequency of Cladocera specimens has made it possible to distinguish eleven zones of their development, which are well correlated with radiocarbon data. The results were compared to those from other sites of north and central Europe. The initial Cladocera development comprises the richest and oldest late Vistulian Cladocera record in Europe. These cladoceran assemblages show that a deep, oligotrophic, moderately coldwater lake was present at the beginning. It appears that the cladoceran development was mainly due to climate change, but also to changes in locally prevailing conditions in the water body. The high frequency of cladocerans, as well as the presence of cladoceran taxa preferring warmer water, was noted before approximately $16 \mathrm{ka} \mathrm{BP}$. The biota suggests that the Oldest Dryas cooling was not severe and fairly variable in terms of humidity and temperature. The changes in Cladocera composition give evidence of what is described as the Intra-Bølling Cold Oscillation. It is also concluded that the Bølling is represented by two phases in the Żabieniec lake sediments.
\end{abstract}

Keywords: subfossil cladoceran, late Vistulian, climate changes, palaeoecology.

\section{INTRODUCTION}

Peatlands are archives of the past and investigations of their characteristics can consequently serve as a basis for reconstructing the conditions under which they were formed. Cladocerans - small crustaceans commonly known as water fleas - are the most abundant crustaceans preserved in lake sediments (Birks and Birks, 1980). The ecological preferences of Cladocera are relatively well understood, so that cladoceran species are good for re-

Corresponding author: D. Pawłowski

e-mail: dominikp@amu.edu.pl

ISSN 1897-1695 (online), 1733-8387 (print)

(C) 2012 Silesian University of Technology, Gliwice, Poland.

All rights reserved. constructing palaeoenvironmental conditions (including trophic status, fluctuations in water level and $\mathrm{pH}$ levels in lakes) and they have been widely used as proxy data for reconstructions of palaeoclimates (Korhola and Rautio, 2001; Kamenik et al., 2007). For many years, and with great success, researchers have used the remains of this fauna in the reconstruction of palaeoenvironmental conditions (Harmsworth, 1968; Szeroczyńska, 1998a; Duigan and Birks, 2000; Hofmann, 2000; Sarmaja-Korjonen et al., 2006). In addition, the response of Cladocera to changes in temperature and humidity is significantly faster than with other proxies (e.g., pollen). Therefore 
some researchers have even stated that climate is the most important factor in the development of the zooplankton to which the Cladocera belong (Patalas, 1990). Correlations between Cladocera frequency and climatic conditions (water temperature and cladoceran temperature preferences) have been studied for many years (De Costa, 1964; Meijering, 1983; Hofmann, 1993; Lotter et al., 1997; Korhola, 1999; Sarmaja-Korjonen et al., 2003; Szeroczyńska, 2006).

A most suitable period for studying these relations is the late Vistulian (i.e., late Weichselian), because many meltwater lakes began to form at that time, and because humans were not yet affecting sedimentary developments. A second reason why the late Vistulian is a suitable period for such studies is the presence of changes that occurred in the composition of the cladoceran species in that time, which indicate frequent fluctuations in temperature (Szeroczyńska, 2006). This period, especially the Late Glacial (i.e., latest Weichselian) is characterized by a series of rapid climatic changes that are recognizable in the oxygen isotope records from Greenland and the Alps (Lotter et al., 1992; Rasmussen et al., 2006; Lowe et al., 2008). Thirdly, this period (between ca. 21 and 11.5 cal ka BP) is known as a transition from the full glacial mode of the Last Glaciation to the interglacial state (Björck et al., 1998).

A phase of the initial development (based on cladoceran data) has been reported from many lakes in central and northern Europe (Szeroczyńska, 1985, 1998a; Duigan and Birks, 2000; Sarmaja-Korjonen et al., 2006). The early developmental stages are difficult to recognize, because they are hardly represented in the sedimentary record due to their short duration: the initial phase is commonly a result of the rapid melting of buried deadice, so most reconstructions focus on the main stage of lake development. Yet the early stages may be helpful in defining the then prevailing palaeoecological conditions. The commonly short-lived initial phase is typically characterized by low biodiversity and by the domination of pioneer species that are tolerant to cold water (so-called arctic species) (Harmsworth, 1968; Whiteside, 1970). This initial cladoceran community is quickly replaced by a more varied and more abundant assemblage of Cladocera, particularly of species requiring warmer water; these species indicate improved edaphic conditions and, indirectly, improved climatic conditions. This development has been reported from many lakes. The lakes of central and northern Europe began to form only exceptionally during the Oldest Dryas, with the Bølling and Allerød being more common starting points (Goulden, 1964; Harmsworth, 1968; Hoffman, 1978, 1993, 2000; Schmidt et al., 1998; Szeroczyńska, 1998a, 2003; Lotter et al., 2000; Gąsiorowski and Kupryjanowicz, 2009).

Previous studies have mainly concentrated on lake and peat sediments deposited during the last $13,000{ }^{14} \mathrm{C}$ years BP, and studies of older sediments are rare (Szeroczyńska, 2006). Few works dealing with Cladocera assemblages from the late Weichselian initial lake developmental stage (older than $13,000{ }^{14} \mathrm{C}$ years BP) have been published so far (Ammann et al., 1985; Szeroczyńska, 1998a; Bennike et al., 2004; Kulesza et $a l ., 2011)$. However, less is known about the period preceding the retreat of the glaciers.

The late Plenivistulian (i.e., late Weichselian) poses difficulties in terms of interpretation because its duration depends on local conditions. Palaeoecological studies based on lacustrine sediments from Europe predating the Late Glacial are scarce despite the fact that this period has been a research topic of interest for several decades. Most studies provide data from the palaeobotanical record (Kolstrup, 1980; Huijzer and Vandenberghe, 1998; Bos et al., 2001; Bohncke et al., 2008). A few present data on the basis provided by other proxies: diatoms (Huber et al., 2010), macrofossils, and coleopterans (Bos et al., 2004), and also chironomids (Engels et al., 2008, Płóciennik et al., 2011). This is connected with the fact that the number of lacustrine records covering parts of the late Weichselian in Europe are limited. Therefore, every study that provides data for the late Plenivistulian is very useful.

The present contribution discusses the results of an analysis of subfossil Cladocera from lacustrine sediments that accumulated during the late Vistulian (approximately $20,000-10,000$ BP) in the Żabieniec lake. This is one of the rare sites in central Poland that is well suited to palaeoclimate studies, and particularly to the analysis of subfossil cladocerans, because of (1) evidence of the late Plenivistulian cladoceran communities and the relatively long persistence of the water body at the site of thickest succession (over $16 \mathrm{~m}$, of which $7 \mathrm{~m}$ is from the late Vistulian), (2) evidence for short-lived oscillations in the biological (cladoceran) records.

This study provides the first cladoceran data estimates for the late Plenivistulian from Poland: the early stage of the Żabieniec lake comprises the richest and oldest Plenivistulian Cladocera record in Poland, and indeed in Europe. The analysis of core samples from the Żabieniec lake provides data on the lake's early environmental evolution under changing conditions and helps to reconstruct the palaeoenvironmental changes which have occurred since approximately $20 \mathrm{ka}$ ago in central Poland and Europe. The conclusions are based on radiometric dating, changes in the frequency of specimens and species of Cladocera and on statistical analysis (Detrended Correspondence Analysis - DCA). The results are compared with those obtained from other lakes from Poland and Europe which have developed since the late Vistulian. The present contribution also provides an answer to the question of what local and global signals can be derived from the analysis of subfossil Cladocera. 


\section{STUDY AREA}

The Żabieniec swamp is located in central Poland (Fig. 1A, B) in the morainic uplands near Łódź (Fig. 1C), between the rivers Mrożyca and Mroga, to the east of the villages of Bielanki and Syberia (Fig. 1D). It is a small peatland (surface area of approximately $25,000 \mathrm{~m}^{2}$ ) situated in an oval depression surrounded by morainic hills. This kettle hole was probably formed during the Late Saalian (Wartanian) and has a very irregular bottom configuration (Lamentowicz et al., 2009). On the lateral part of this kettle hole (in another part of the peatland), Eemian/Early Vistulian deposits have also been found, but the Żabieniec basin is situated in the central part of this depression where periglacial clastic material has filled the basin since the Weichselian. The main infilling is, however, biogenic, consisting of gyttja and various types of peat, which formed between the Late Glacial and the Holocene. The biogenic deposits only occur in the deepest part of the depression and the 16.15 metre deep profile analysed in this study was taken from this location. Detailed lithological and geomorphological descriptions of the Żabieniec site are presented elsewhere (Balwierz et al., 2009; Twardy et al., 2010).

The lowermost sediments in the depression are sands. Above, at a depth of 16.15-14.50 m, mineral silts have been documented. They are overlain to a depth of about $12.40 \mathrm{~m}$ by mineral and organic silts (Fig. 2). Then come the biogenic sediments studied here: gyttja with silt and detritus-clay gyttja $(12.40-8.80 \mathrm{~m})$. The radiocarbon data (Lamentowicz et al., 2009) indicate that the deposition of the above sediments (depth $16.15-8.80 \mathrm{~m}$ ) took place during the late Vistulian.
The climate in the study area is transitional (Woś, 1999) with more continental than oceanic influences; it is drier than the northern part of the Poland, which is more influenced by wet air masses from the Baltic and the northern Atlantic. The mean annual rainfall ranges from 500 to $600 \mathrm{~mm}$. The growth period lasts for 210 days. The mean monthly air temperature varies from $-3^{\circ} \mathrm{C}$ in January to $17.9^{\circ} \mathrm{C}$ in July, while the mean annual temperature is $7.6-8.0^{\circ} \mathrm{C}$ (Kłysik, 2001). Snow cover is present for an average of 50 to 70 days annually.

\section{MATERIALS AND METHODS}

The investigation concerned 148 samples taken from the Z-2 core (depth $16.15-8.80 \mathrm{~m}$ ) at $0.05 \mathrm{~m}$ intervals. Samples of $1 \mathrm{~cm}^{3}$ were processed according to the standard procedure (Frey, 1986). Each sample was treated with $\mathrm{HCl}$ to eliminate carbonates and boiled for half an hour in a $10 \%$ solution of $\mathrm{KOH}$ with a magnetic stirrer to deflocculate the material, so as to remove humic matter. Subsequently, the residue was washed and sieved using a $50 \mu \mathrm{m}$ sieve. The final residue was brought up to $10 \mathrm{ml}$ with distilled water and coloured with safranine dye before counting. A solution of $0.1 \mathrm{ml}$ was used for every microscope slide. All Cladocera remains were counted: headshields, shells, postabdomens, postabdominal claws and ephippia. For each taxon, the most abundant body part was taken to represent the number of individuals, and percentages were calculated from the sum of individuals. The taxonomy of cladoceran remains used in the present contribution follows Szeroczyńska and Sarmaja-Korjonen (2007). Three to five slides (each $0.1 \mathrm{ml}$ ) were examined for each level and the total concentration per $\mathrm{cm}^{3}$ was calculated.

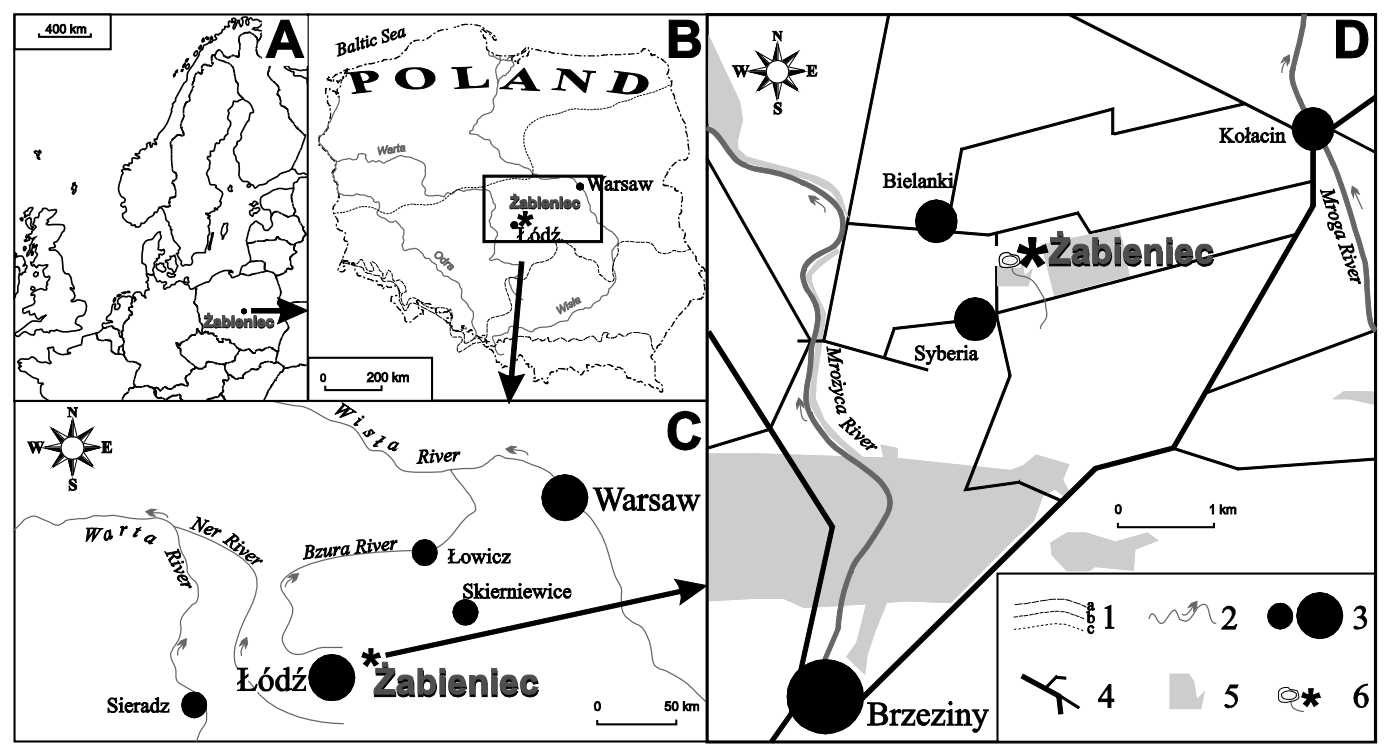

Fig. 1. Location of the Żabieniec site in Europe $(A)$, and in Poland $(B, C, D) .1=$ Extent of Polish glaciations: $a=$ Elsterian, $b=$ Saalian, $c=$ Vistulian (Weichselian); 2 = rivers; 3 = towns, villages; 4 = roads; 5 = forests; $6=$ Żabieniec peatland. 

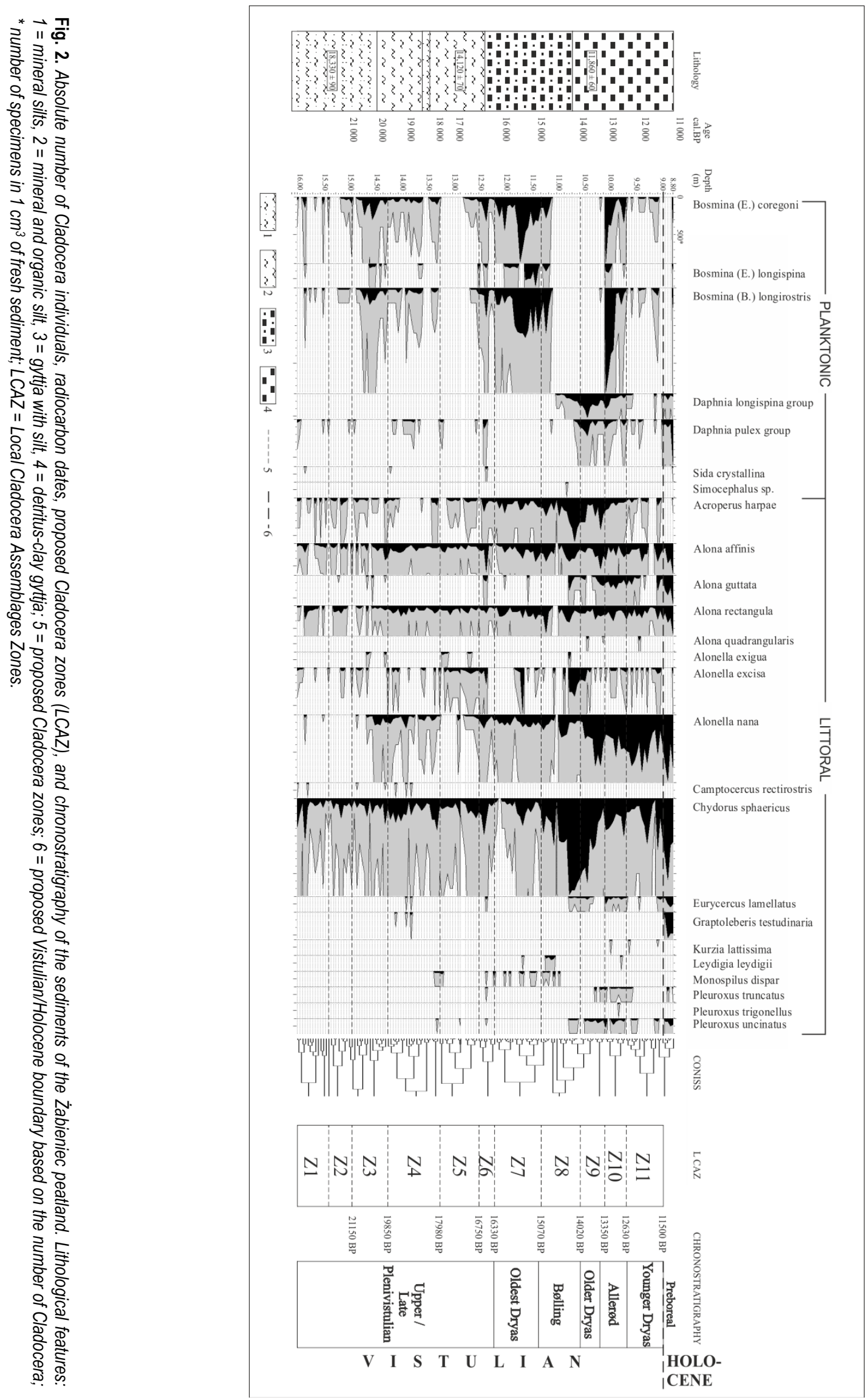
Both the presence and the frequency of Cladocera species were used to reconstruct the development of the Żabieniec lake. Based on the composition and abundances of species, Cladocera developmental zones were distinguished (Fig. 2). CONISS program (Grimm, 1987) confirmed that the assigned Cladocera zones (Local Cladocera Assemblage Zones: LCAZ) are correct. The cluster analysis applied for the purpose was based on the constrained incremental sum of squares clustering. Only species with at least $5 \%$ abundance at each level were included in the statistical calculations. The results were plotted in a relative abundance diagram using POLPAL software (Walanus and Nalepka, 1999). The ecological preferences of the various cladoceran taxa are based on Whiteside (1970) and Szeroczyńska (1998b).

The first stratigraphic framework for the Żabieniec site was presented by Lamentowicz et al. (2009), but here a new stratigraphic framework was established through new age-depth model for the whole profile; it was constructed on the basis of the radiocarbon dates of the organic material (Fig. 3). Material for radiocarbon dating was obtained on the basis of macroscopic plant remains (i.e. Sphagnum stems), avoiding any rootlets and other contamination (Lamentowicz et al., 2009). Some of the samples were dated using accelerator mass spectrometry (AMS); all other samples were dated using radiometric methods (Lamentowicz et al., 2009). A newly constructed age-depth model, based on all 11 radiocarbon dates, and spread over the time period since 22,000 cal BP (Fig. 3 ), is presented here. Conventional radiocarbon dates were calibrated using OxCal 4.1 (Bronk Ramsey, 2009) and the IntCal09 calibration curve (Reimer et al., 2009); the model was also constructed using the $\mathrm{P}$ _Sequence procedure from OxCal 4.1 programme - the same method used in the article of Lamentowicz et al. (2009) and using the same value of the parameter $k=0.1$. Remaining procedure (interpolation by the Akima spline algorithm (Akima, 1970)) was also used to give the date for each centimetre of depth. Dates are given in calibration years BP (Table 1).

Detrended Correspondence Analysis (DCA) is a multivariate statistical technique widely used to discover the main factors in species-rich data matrices (Hill and Gauch 1980). This technique, with detrending by segments and down-weighting of rare species, was performed on the square-root transformed abundance data to compare the amount and timing of the changes in Cladocera composition. The analysis was performed for the late Vistulian with the objective of discovering the main factors and gradients driving assemblage successions. The DCA was performed using the software CANOCO 4.5 (Ter Braak and Smilauer, 2002).

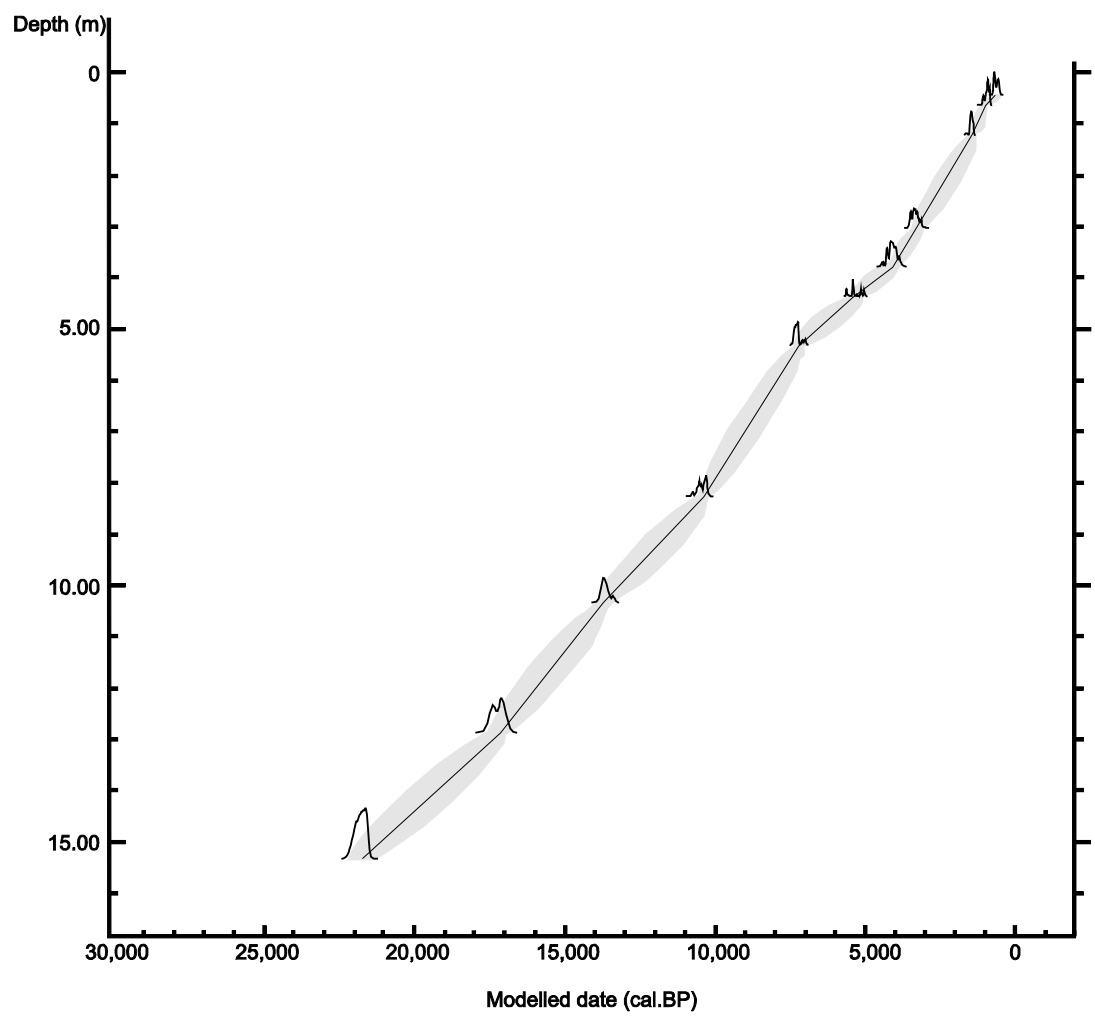

Fig. 3. Age-depth model: entire profile. 


\section{RESULTS}

The late Vistulian sediments of the Żabieniec peatland contain 25 Cladocera species (Fig. 2) belonging to 4 families. The most numerous are the littoral species of the Chydoridae family. The number of pelagic forms (from the Bosminidae, Daphnidae and Sididae families) exceeded in places $50 \%$ of the total number of Cladocera individuals.

The vertical changes in the species composition of Cladocera in the sediments from the Żabieniec lake allow us to distinguish 11 zones ( $\mathrm{Z} 1$ through $\mathrm{Z} \mathrm{11;} \mathrm{Figs.} \mathrm{2,} \mathrm{4).}$ The main criterion for distinguishing zones was the results of cluster analysis (application of CONISS). The Żabieniec basin started to develop in the late Vistulian (Table 1; Figs. 2, 3). Zones $Z 1$ through $Z 6$ date from the end of the Vistulian glaciation (late Plenivistulian), and zones $Z 7$ through $Z 11$ date from the Late Glacial (from the Oldest Dryas to the Younger Dryas). No Cladocera have been found at depths of $16.15-16.05 \mathrm{~m}$.

Zone $\mathbf{Z} 1$ (16.05-15.45 m) dates from approximately $22,000 \mathrm{cal}$. BP and is characterized by the dominance of species belonging to the littoral zone (Chydorus sphaericus (which occur very rarely in the pelagic zone, see Szeroczyńska (1998b)), Alona rectangula, Alona affinis, and Acroperus harpae). Planktonic species are also either common (Bosmina (Eubosmina) coregoni) or occur in smaller numbers (Bosmina (Eubosmina) longispina and Bosmina longirostris). Taxa of the Daphnia pulex group have been identified. The number of individuals initially exceeds $1000 / \mathrm{cm}^{3}$, and 8 species of Cladocera occur in the lower part of this zone (Fig. 4). Only 100 individuals per $\mathrm{cm}^{3}$ and 4 species occur in the upper part.

Table 1. Results of radiocarbon dating

\begin{tabular}{lccc}
\hline $\begin{array}{l}\text { Sample } \\
\text { name }\end{array}$ & $\begin{array}{c}\text { Depth } \\
(\mathbf{c m})\end{array}$ & $\begin{array}{c}{ }^{14} \mathrm{C} \text { age } \\
(\mathrm{BP})\end{array}$ & $\begin{array}{c}\text { Calibrated age (cal BP) } \\
95.40 \% \text { conf. intervals }\end{array}$ \\
\hline Poz-19019 & 45 & $645 \pm 50$ & $674-545(95.4 \%)$ \\
\hline Poz-17117 & 60 & $1085 \pm 30$ & $1056-935(95.4 \%)$ \\
\hline Poz-17116 & 120 & $1475 \pm 35$ & $1415-1298(95.4 \%)$ \\
\hline Lod-1391 & 305 & $3010 \pm 50$ & $3359-3063(95.4 \%)$ \\
\hline Lod-1390 & 375 & $3690 \pm 50$ & $4220-4208(0.8 \%)$ \\
\hline & & & $5155-3886(94.6 \%)$ \\
\hline Poz-23658 & 436 & $4580 \pm 35$ & $5448-5385(18.2 \%)$ \\
& & & $5241-5239(0.2 \%)$ \\
\hline Poz-23638 & 531 & $6270 \pm 40$ & $5223-5217(0.5 \%)$ \\
\hline Poz-23639 & 826 & $9130 \pm 50$ & $104717-7025(9,0 \%)$ \\
\hline Poz-23640 & 1036 & $11860 \pm 60$ & $10423-10204(94.2 \%)$ \\
\hline Poz-23659 & 1290 & $14120 \pm 70$ & $17521-16901(95.4 \%)$ \\
\hline Poz-29713 & 1535 & $18330 \pm 90$ & $22236-21511(95.4 \%)$ \\
\hline
\end{tabular}

Zone $\mathbf{Z} 2(15.45-15.00 \mathrm{~m})$ dates approximately $22,000 \mathrm{BP}$ (to approx. 21,150 cal. BP), and is characterized by littoral species (Chydorus sphaericus, Alona rectangula, Alona affinis, and Acroperus harpae). Planktonic species (in relation to the previous zone) are present only in the upper part. Except for one sample, the number of individuals does not exceed 300 per $\mathrm{cm}^{3}$.

Zone $\mathbf{Z} 3(15.00-14.30 \mathrm{~m})$ dates from approximately 21,150 to 19,850 cal. BP, and is characterized by an increase of planktonic species, in particular Bosmina longirostris. Among the littoral forms, Chydorus sphaericus, Alonella nana, Alona affinis, Alona rectangula, and Acroperus harpae dominate. The Cladocera increase in both frequency and diversity (more than 500 specimens and 11 species per $\mathrm{cm}^{3}$ of deposit).

Zone Z 4 (14.30-13.30 m) dates from approximately 19,850 to $17,980 \mathrm{cal}$. BP and is characterized by a consistent decrease in both the frequency and diversity of the Cladocera. Chydorus sphaericus, Alonella nana, Alona rectangula, and Alona affinis dominate. Species from the Daphnia pulex group and, in small numbers, Camptocercus rectirostis and Graptoleberis testudinaria, also appear. At the end of the zone, Pleuroxus uncinatus, and Monospilus dispar appear, while planktonic forms diminish.

Zone Z 5 (13.30-12.55 m) dates from approximately 17,980 to $16,750 \mathrm{cal}$. BP. It is characterized by a significant drop in the number of Cladocera. The frequency and diversity of cladoceran fauna rapidly decrease (with 400 specimens and 5 species per $\mathrm{cm}^{3}$ of deposit). Planktonic forms are almost absent. Only a few littoral forms occur, viz. Chydorus sphaericus, Alona rectangula, Alona affinis, Acroperus harpae, Alonella excisa and Alonella nana.

Zone Z 6 (12.55-12.25 m), which dates from approximately 16,750 to $16,330 \mathrm{cal}$. BP, is characterized by the rapid development of the Cladocera fauna, as shown by a sudden increase in the frequency and diversity of Cladocera (with over 2,000 specimens and 16 species per $\mathrm{cm}^{3}$ of deposit). Planktonic species from the Bosminidae and Daphnidae families are present. Among the littoral forms, Chydorus sphaericus, Alonella nana, Alona affinis, Acroperus harpae, and Alonella excisa dominate. Species from the genus Pleuroxus as well as Monospilus dispar appear in small numbers.

Zone $\mathbf{Z} 7(12.25-11.35 \mathrm{~m})$, dating from approximately 16,330 to $15,070 \mathrm{cal}$. BP, is characterized by a rapid increase in planktonic forms. Species belonging to the Bosminidae family (Bosmina (E.) coregoni and B. longirostris) dominate. Among the littoral forms, Chydorus sphaericus, Alonella nana, Alona affinis, Acroperus harpae, Alona rectangula, and Alonella excisa appear. Monospilus dispar and Leydigia leydigii appear in small quantities. The number of species remains more or less constant (at 9), but the frequency of cladoceran specimens increases (with over 3,000 specimens per $\mathrm{cm}^{3}$ of deposit). 


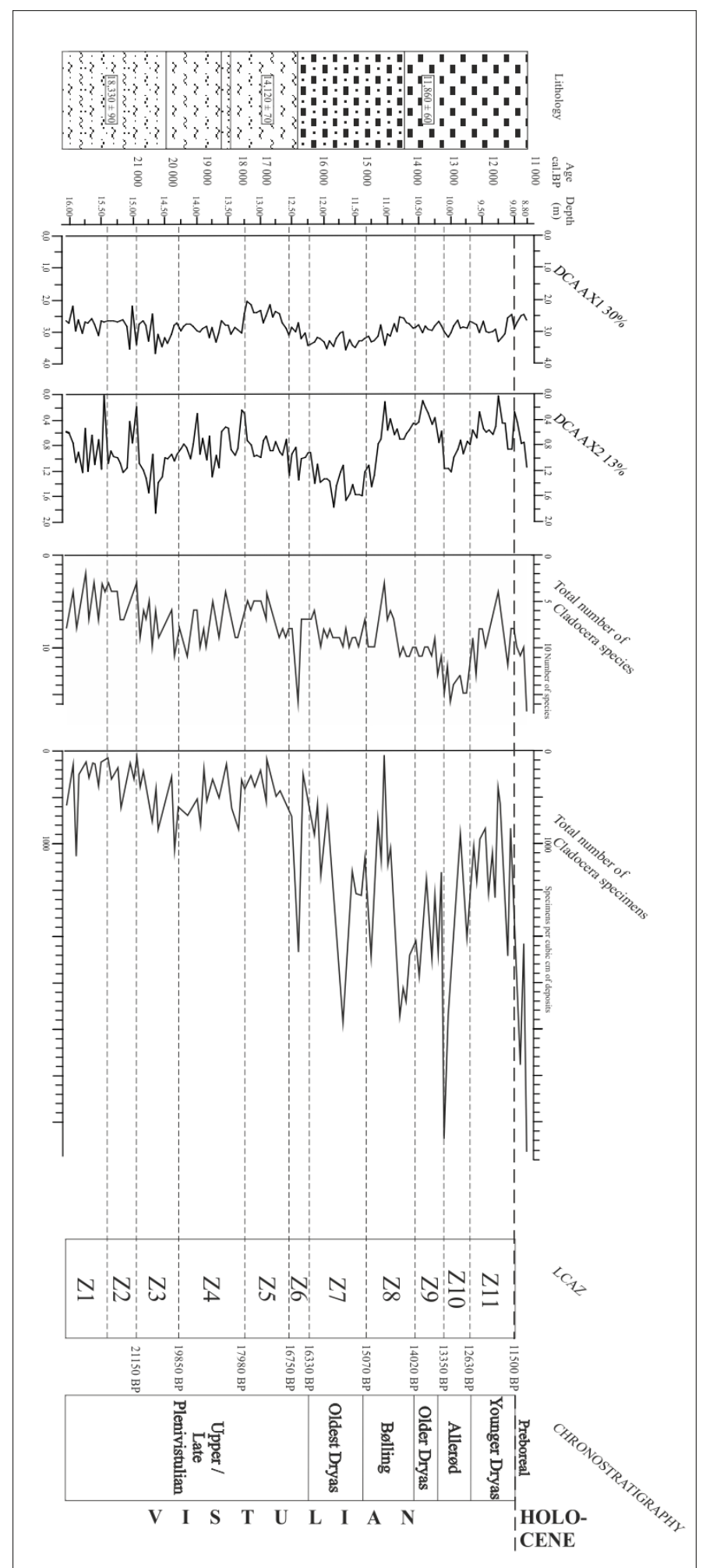


Zone Z 8 (11.35-10.60 m), which dates from approximately 15,070 to $14,020 \mathrm{cal}$. BP, is characterized by the disappearance of the Bosminidae family and the appearance of the Daphnidae family (Fig. 2). Chydorus sphaericus, Acroperus harpae, Alona affinis and Alonella excisa dominate. Species such as Alona rectangula, Alona guttata, Pleuroxus uncinatus, Leydigia leydigii, Monospilus dispar and Eurycercus lamellatus appear. In the middle part of the zone, the frequency and diversity of the cladoceran fauna decreases rapidly (from 2,000 to 100 specimens, and from 10 to 3 species per $\mathrm{cm}^{3}$ of deposit, respectively). At the end of the zone, the frequency and diversity of the cladoceran fauna again increases (to almost 3,000 specimens and 11 species per $\mathrm{cm}^{3}$ of deposit, respectively).

Zone Z 9 (10.60-10.15 m), dating from approximately 14,020 to $13,350 \mathrm{cal}$. BP, is characterized by a slow decrease in frequency of the Cladocera (to 1,300 specimens per $\mathrm{cm}^{3}$ of deposit). From among the planktonic forms, only the ephippia of the Daphnia pulex and of Daphnia longispina groups occur. The Chydoridae increase sharply; Chydorus sphaericus, Alonella nana, Acroperus harpae and Alona affinis dominate. At the end of the zone, Pleuroxus uncinatus, Pleuroxus truncatus (Peracantha truncata) and Alona quadrangularis appear. The frequency of Chydorus sphaericus decreases consistently at the end.

Zone $\mathbf{Z} 10$ (10.15-9.70 m), dating from approximately 13,350 to 12,630 cal. BP, is characterized by the appearance of the Bosminidae family, in particular Bosmina longirostris. The largest development in Cladocera fauna occurred in the beginning of this zone, with an increase in frequency and diversity (with as many as 4,000 specimens and 16 species per $\mathrm{cm}^{3}$ of deposit). Among the littoral forms, Chydorus sphaericus and Alonella nana dominate. Species such as Pleuroxus truncatus, Pleuroxus uncinatus and Pleuroxus trigonellus appear.

Zone $\mathbf{Z} 11$ (9.70-9.00 m), dating from approximately 12,630 to $11,500 \mathrm{cal}$. BP, is characterized by a continuous decrease in frequency and diversity of Cladocera, to 4 species and 300 specimens per $\mathrm{cm}^{3}$ (at depth $9.20 \mathrm{~m}$ ). Alonella nana dominates. Planktonic forms occur sporadically. At the end of the zone, the frequency of species increases rapidly to 12 and the number of specimens to 2,500 per $\mathrm{cm}^{3}$ (at the depth of $9.10 \mathrm{~m}$ ).

\section{Numerical analysis}

The main trends in the succession are shown by the DCA results (Fig. 4). The position of the samples and species on DCA axis 1 reflect the water-level gradient (based on planktonic and littoral frequency). The samples reflect deeper water (increase in frequency of planktonic forms). The positions of the samples and species along DCA axis 2 represent a signal similar to the temperature/climate change. The shifts mainly reflect gradual changes in the frequency of Cladocera species and specimens.
For the late Plenivistulian, the values on DCA axis 1 vary (especially from 16.00 to $14.50 \mathrm{~m}$ ). From $Z 1$ to $Z 4$, the values decrease and increase rapidly. From $Z$ 5, where the lowest values exist, an increase follows to $Z 7$. Then again, from $Z 8$ on, the DCA axis 1 values show a gradually decreasing trend.

The pattern of Cladocera values on DCA axis 2 (Fig. 4) for the late Plenivistulian shows many variations (high and low values) which occurred after the lake had formed. Some of them are related to the pattern of Cladocera DCA axis 1 values, and might reflect lake-level oscillations. The Late Glacial samples and species from the Oldest Dryas to the Younger Dryas/Preboreal (early Holocene) are mostly related to variations of the DCA axis 2 values, which show a decreasing trend in the Older Dryas and Younger Dryas and in parts of the Bølling. The values sharply increase in the Allerød and somewhat in the Bølling. Worth mentioning is the increase in the Oldest Dryas and late Plenivisulian (where the highest values are reached).

\section{DISCUSSION}

\section{The Late Vistulian history of the Żabieniec Lake}

Cladocera and radiocarbon data are consistent: the boundaries of the cladoceran zones correspond to the stratigraphic boundaries found by radiocarbon dating. Cool phases are, as a rule, reflected by a rapid decrease in the number of Cladocera individuals and by diversity, as well as by the presence of 'arctic species' in the lake (Figs. 2, 4); warm phases show a higher cladoceran diversity, a higher number of specimens and a greater presence of warm-water species (Figs. 2, 4). Both situations are also reflected in changes of the values of the DCA axes, particularly DCA axis 2. Generally, the climatic periods distinguished here correlate with the well-dated varve chronology from Lake Gościąż, Poland (Goslar et al., 1998) and from other European sites (Litt et al., 2001). Additionally and in general, the changes in Cladocera species composition and the frequency of specimens in the Żabieniec basin closely resemble those described in other Polish and European lakes (Goulden, 1964; Harmsworth, 1968; Hoffman, 1978, 2000; Ammann et al., 1985; Szeroczyńska, 1985, 1998a, 2003; Lotter et al., 2000; Schmidt et al., 1998; Bennike et al., 2004). There are, however, some differences. These mainly concern the beginning of lake development, and the conditions obtaining during the Oldest Dryas and the Bølling.

Zones Z 1-Z 6 show the early stages of the lake history, probably at the end of the Vistulian glaciations. The lowermost radiocarbon data of the investigated profile, at a depth of $15.35 \mathrm{~m}$, was dated as approximately 22,000 cal. BP (Table 1), which suggests the late Plenivistulian (Last Glacial Maximum). The material was carefully selected for radiocarbon dating, and thus partially eliminated, or at least restricted the 'reservoir effect', but with- 
out the ability to better clarify the age of adjacent layers of the core (which requires further dating), it is still difficult to exactly indicate its stratigraphic position. This was, however, a time of colonization of the lake by Cladocera (Fig. 2), characterized by a still low frequency of Cladocera specimens. Compared to the rest of the profile, the number of individuals is small, but eight species of Cladocera already appear in Z 1 (Fig. 4). These species are those tolerant to cold water (so-called arctic species), such as Acroperus harpae, Alona affinis and Chydorus sphaericus (Harmsworth, 1968; Whiteside, 1970). This pioneer Cladocera community indicates a cold climate. The frequency of Cladocera increased quickly (Fig. 4), reaching 11 species in Z 3, which suggests favourable conditions. The values of DCA axis 2 (temperature/climate change) also increased during this period.

Initially the lake was shallow, but with time it deepened, as indicated by the increasing dominance of planktonic species (Fig. 2) and the diversity of the cladocerans. This may have resulted from the increase of the water volume in the basin (and perhaps from slight warming). The greater diversity (the permanent presence of $8-10$ species), and the presence of more demanding species such as Bosmina longirostris, Alona rectangula and later Monospilus dispar (Whiteside, 1970; Hofmann, 1986) suggest slightly better edaphic conditions (higher productivity and perhaps more food for the cladocerans), but the lake remained oligotrophic (as shown by the presence of the Bosmina (Eubosmina) taxa, which prefers oligotrophic conditions (Flössner, 1972; Korhola, 1999)). The presence of species such as Alona affinis and Acroperus harpae which live directly on the mineral bottom, but also among plants (Whiteside, 1970), suggests that the basin became very slowly inhabited by plants. The water level of the lake probably rose, as is reflected by the abundance of Bosminidae and Daphnidae, particularly the Bosmina longispina and Daphnia pulex group, species typical of the open-water zone. The Cladocera community indicates slightly colder climate conditions, but the temporary appearance (in Z 4) of species preferring warm waters (Poulsen, 1928), such as Graptoleberis testudinaria, Camptocercus rectirostris, Pleuroxus uncinatus and Monospilus dispar, suggests favourable overall climate conditions. Their number is small and their appearance is related to improved edaphic conditions (the summer temperature perhaps became higher). In zone $\mathrm{Z} 5$, the overall conditions of the lake changed. The frequency and diversity of Cladocera, and especially of planktonic forms, decreased. These changes are related to the presence of cold-tolerant forms, and they show deterioration in living conditions in the basin. The values of DCA axis 1 (a water-level gradient) and DCA axis 2 (temperature/climate change) also decreased. The water volume of the lake may have diminished (shown by the disappearance of planktonic forms and the exclusive presence of Cladocera species associated with silty sediments and vegetation), but the Cladocera changes may also be due to cooling. A sample from $12.90 \mathrm{~m}$ was dated at approximately 17,000 cal. BP, thus indicating that this change could have taken place in the late Plenivistulian. In zone $\mathrm{Z} \mathrm{6}$, the water level of the lake probably rose again, as reflected by the appearance and increase of planktonic forms (Figs. 2, 3), particularly from the Bosminidae family and the Daphnia pulex group. The increase in the total number of both species (to 16) and individuals suggests more favourable hydrological conditions and slightly higher productivity in the lake. This was possibly due to a slight amelioration of the climate, as suggested by the presence of Cladocera species preferring warm water (Poulsen, 1928), such as Pleuroxus truncatus and Pleuroxus uncinatus. Also the values of DCA axis 1 and DCA axis 2 increased, possibly due to a change in humidity.

Zone $\mathbf{Z} \mathbf{7}$ dates from the Oldest Dryas. This zone is characterized by a gradually increasing frequency of Cladocera (Fig. 4), especially of planktonic forms from the Bosminidae family (Fig. 2); this suggests stepwise changing conditions in the lake. These changes suggest initially favourable conditions (rising water level) and later also a slightly higher productivity (and perhaps a slightly higher temperature) in the lake. This is confirmed by the presence of Bosmina longirostris, Leydigia leydigii and Monospilus dispar (which does not live in cold water), but the presence of Bosmina (E.) longispina and $B$. (E.) coregoni (Hofmann, 1986) indicates oligo- to mesotrophic conditions in the lake. The results of the DCA analysis also partly confirm better conditions in the basin: the values of the DCA axis 2 increased, while those of the DCA axis 1 also show a gradual increase.

Zone $\mathbf{Z ~} 8$ dates from the Bølling. The cladoceran community indicates an overall mild climate and favourable conditions (a large number of both species and individuals). Also, the frequency of species such as Bosmina longirostris, Chydorus sphaericus, Monospilus dispar, Leydigia leydigii and Alona rectangula as well as species of the genus Pleuroxus, which are considered to indicate more trophic water, suggests higher edaphic conditions (Monospilus dispar was suggested by Røen (1995) to indicate a change to meso-/eutrophic conditions). During the middle part of the Bølling, however, a rapid decrease in the number of individuals and in the diversity of the cladoceran fauna indicates changing conditions (Fig. 4). The lake probably had the same, or only slightly lower, water level, as indicated by the disappearance of Bosminidea which was connected with the appearance of the Daphnidae and especially with the presence of the Daphnia longispina group (Fig. 2). These are species typical of open water. This is also confirmed by the results of the DCA analysis, i.e. by the values of the DCA axis 1 that show a very slow decrease.

It is thus possible that these changes resulted from a temporary cooling (the values of DCA axis 2 rapidly decreased; see Fig. 4). For the Bølling, favourable conditions for zooplankton have been described (Ammann et 
al., 1985; Szeroczyńska, 1998a, 2006; Bennike et al., 2004), but the Cladocera compositions from the Żabieniec sediments are represented by two phases (Figs. 2, 4). The first phase is indeed characterized by good edaphic conditions, the presence of planktonic forms, and species preferring warm water living in association with aquatic plants. The second phase, however, represents worse conditions in the lake, with an increase in the frequency of 'arctic' species (especially Chydorus sphaericus). A comparable situation has not been reported for cladoceran compositions from other sites in Poland or from the chironomid data-set (Płóciennik et al., 2011), but is consistent with palynological data from other Polish lakes (Ralska-Jasiewiczowa et al., 1998). Regarding climatic conditions, the first phase of the Bølling was warmer, whereas the second was a bit cooler, with less humidity (Goslar et al., 1998). It cannot be fully excluded, however, that the second phase represents the Intra-Bølling Cold Oscillation (Koç Karpuz and Jansen, 1992), which is also known to be characterized by a strong decrease in the number of species and specimens of Cladocera (Fig. 4). At the present stage of research, this is a hypothesis, because such situations might be also connected to local conditions. For example, in a warm climate the growth of algae could result in an increase in Chydorus sphaericus and a decrease in the zooplankton in reservoir (Szeroczyńska, 1998b).

Zone $\mathbf{Z} 9$ dates from the Older Dryas (as confirmed by radiometric dating). The specimens of Cladocera species that are resistant to changing ecological conditions (Chydorus sphaericus, Acroperus harpae, Alonella nana and Alona affinis), including those that can live in cold water, increased. The species composition indicates a decrease in water temperature and a general cooling. This is supported by the smaller number of species and individuals (compared to the Bölling), and also by the rapid decrease in the values of DCA axis 2 (Fig. 4). The general trend of cooling described above in the Older Dryas period is widely known from lakes in Poland (Szeroczyńska, 1985, 1998a, 2003, 2006; Kulesza et al., 2011) and in Europe (Hofmann, 1978; Ammann et al., 1985; Bennike et al., 2004). The presence at the end of this zone of a stenothermal species (i.e. Pleuroxus sp.) suggests improving conditions, probably connected with following warmer period (Allerød).

Zone $\mathbf{Z ~} 10$ dates from the Allerød (Fig. 2), as confirmed by radiocarbon dating. The environmental conditions were improved. Water temperature increased, which is confirmed by the presence of Pleuroxus truncatus, Pleuroxus trigonellus and Pleuroxus uncinatus, all species being stenothermal and requiring warm water (Whiteside, 1970). The dominance of planktonic species suggests a higher water level in the lake. At the same time, the frequency of cold-tolerant species (Acroperus harpae and Chydorus sphaericus) decreased. The improved edaphic conditions in the basin are supported by the highest number of species and individuals in the en- tire profile (Fig. 4). The values of DCA axis 2 show an increasing trend (warming) and the values of DCA axis 1 also show a slight increase (Fig. 4). The relatively warm Allerød is a very recognizable period in the lake's development. Productivity was highest at the beginning of the Allerød, as evidenced by higher Cladocera concentrations, which decreased again towards the end of the $\mathrm{Al}$ lerød. The species composition from the Żabieniec site suggests that the Allerød was warmer than the preceding period (as indicated by a large number of species and individuals) and that the second part of the Allerød was probably as warm as the Holocene (as indicated by the presence of "warm" cladoceran taxa, such as Pleuroxus trigonellus, which colonized the lake before the Holocene). Favourable conditions for the development of zooplankton during the Allerød have been described from all lakes in Poland with sediments from this stage (Szeroczyńska, 1985, 2003, 2006; Kulesza et al., 2011); the same holds for Europe (Goulden, 1964; Harmsworth, 1968; Hofmann, 1986, 1993; Bennike et al., 2004).

Zone $\mathbf{Z} 11$ dates from the Younger Dryas. This part of the Żabieniec profile indicates a change in environmental conditions in the basin. Among the littoral forms, Alonella nana (a species living in clean water between plants, but also in colder waters: Hofmann, 2000) and Chydorus sphaericus dominated at the end of the zone. The decrease in the number of planktonic forms and the presence of cold-tolerant species (Alonella nana, Chydorus sphaericus, and Alona affinis) indicate a cooling, which is attributed to the Younger Dryas. The values of DCA axis 2 also show a decreasing (cooling) trend (Fig. 4). The clear decline in the number of species to as few as 4 at a depth of $9.20 \mathrm{~m}$ (Fig. 4), and the decline in the total number of individuals to below 300 per $\mathrm{cm}^{3}$ is likely to reflect a change in environmental conditions in the basin in the form of a lower water temperature. This part of Younger Dryas was one of the colder phase duration the developments of the Żabieniec lake. The changes in the Cladocera fauna from Żabieniec show however, that the Younger Dryas cannot be identified as a truly very cold stage, because the cladoceran concentrations increased towards the end. Additionally, planktonic forms preferring more favourable environmental conditions occur, as do littoral forms which live in warmer water (genus Pleuroxus). Perhaps this part corresponds to a warmer phase of the Younger Dryas. The appearance of species belonging to the genus Pleuroxus indicates the influence of a mild climate, so that it seems that the Younger Dryas cooling was not severe. These changes are similar to others found in lakes from Poland (Szeroczyńska, 1998a, 2006) and other European countries (Hoffman, 2000; Lotter et al., 2000; Bennike et al., 2004). The boundary between the Younger Dryas and the Preboreal is indicated at the Żabieniec site by a rapid increase in the diversity of taxa and the number of individuals and by the appearance of species preferring warm water and living in open water (Figs. 2, 4). This suggests better edaphic conditions 
in the basin as a result of an increase in temperature. Similar situations have been described in other lakes (Duigan and Birks, 2000).

\section{Early stages of the Żabieniec Lake}

The changes described in the Cladocera frequency in the early stage of the Żabieniec lake are among the oldest cladoceran records from Europe during the late Plenivistulian. On the other hand, the environmental conditions are difficult to compare with other cladoceran data. In addition, due to the small number of radiocarbon dates of Plenivistulian sites from Poland, debate continues on the precise location of these events in time (Rotnicki and Borówka, 1995; Mojski, 2005), especially in models of chronological age.

Temperature plays a direct role on the productivity, life history, and reproduction of cladocerans (Keller et al., 1999). It is one of the most important factors in influencing the abundance and richness of Cladocera, but this group are influenced by a wide variety of factors apart from temperature. For example, cladocerans are also dependent on primary production, and are frequently regulated by fish predation (Gliwicz et al., 2001). However, in the Żabieniec lake there is a no evidence of fish predation in these times. Since we have noted evidence for rapid climate change in the northern hemisphere in the period between 21 and 11.5 cal ka BP, temperature cannot be ignored as one of the more important drivers of cladoceran assemblages. It is postulated that the highest variation in the cladoceran fauna recorded might be a consequence of sensitivity to temperature, but locally prevailing conditions cannot be excluded. For the above reasons, the Żabieniec lake can help in the reconstruction of late Plenivistulian palaeoenvironment events.

In the Żabieniec lake, the Cladocera record from the late Plenivistulian suggests unstable conditions. This is confirmed by the results of the curves of the DCA (Fig. 4), indicating fluctuating conditions. The cladoceran community probably reflects periglacial conditions during the first phase of melting of dead-ice blocks and the formation of the basin. The species composition and specimen frequency initially show a picture which resembles those of the pioneer species that initially dominated many lakes of central and northern Europe (Szeroczyńska, 1985, 1998a, 2006; Duigan and Birks, 2000; Lotter et al., 2000; Hofmann, 2000; Bennike et al., 2004; Sarmaja-Korjonen et al., 2006), but the Żabieniec lake is older (approximately $22 \mathrm{ka}$ cal BP). Similar results were obtained based on the chironomid data-set (Płóciennik et al., 2011) which suggests cool conditions in the late Pleniglacial, which may correspond to the cold oscillation recorded at Żabieniec at a core depth $14.50 \mathrm{~m}$, before the Bølling period.

The quick increase in the frequency of Cladocera, and especially the growth and dominance of planktonic species, suggest favourable conditions. This may have resulted from an increase in the water volume of the basin (and perhaps a slight warming). The fluctuating but overall rising water-level in the Żabieniec basin results probably from the summer drainage of meltwater from the active permafrost zone (shallow groundwater) and/or the slow(?) melting of dead-ice, which may have resulted in the continuous presence of water at the bottom of the basin. Mineral material may have been supplied by winds blowing occasionally over the frozen lake carrying material from the sedimentary cover of dead-ice blocks. This is suggested by the presence of mineral particles in the sediment (e.g., more sandy layers at a depth of 13.50 $13.65 \mathrm{~m})$. It is possible that the formation of the lake resulted from changes in the hydrological situation, more specifically from increased precipitation or a reduction in evaporation and disappearance of permafrost, as suggested by Marks (1996), for lakes that formed in the Late Glacial. If so, the deepening of the basin resulted from a rising water level, not from subsidence of the bottom due to melting of underlying dead-ice blocks. It is, however, still difficult to reconstruct with certainty the conditions and nature of the process which caused this effect. The second most probable explanation of this situation is that the Żabieniec lake was a kind of thermokarst lake (a socalled thaw lake). An abrupt climate warming following a prolonged cold (stadial) period could lead to permafrost degradation and the formation of thermokarst lakes. This suggests that the response to a sudden and relatively short climate warming could be documented in the infill of such a thaw lake (Bohncke et al., 2008). The temperature reconstruction described for chironomid assemblages also begin to rise at about $13.55 \mathrm{~m}$ (Płóciennik et al., 2011). This situation is very similar to the changes described here and the cladoceran data presented here, but the explanation of most changes described here must be considered as tentative; part can probably be attributed to local conditions that were related to the initial stage of lake formation (the early stage had very unstable conditions).

The later improved habitat conditions can be attributed to an increase in the lake's water level. This is consistent with the results of DCA analyses: the pattern of Cladocera DCA axis 1 values (Fig. 4) correspond with those of DCA axis 2, and show oscillations in lake level due to an unstable climate. The question remains of whether this record illustrates the decline of the late Plenivistulian, which may correlate with the warmer climate oscillation called the 'Epe (Kamion) Interphase' (Kolstrup, 1980; Manikowska, 1995). It is possible that some of changes described above also correspond to the short-term amelioration of the climate that has been documented during the period 17.0-16.2 ka BP (Lowe et al., 2008), but at the current stage, this is only a hypothesis, because problems in the identification of short-term climatic events during this cold period are still frequently encountered (correlation between the ice-core record and the terrestrial botanical record still remains unclear).

The Oldest Dryas is also very interesting with respect to the development of the Żabieniec lake because there 
were cold-tolerant forms which were, however, very quickly replaced by taxa that prefer better edaphic conditions and that live in open water (species from the Bosminidae family). The increase in the total number of individuals suggests, like the results of DCA, a higher productivity in the lake during more favourable conditions. This is very surprising and difficult to explain, because (1) the changes suggest mild climatic conditions, a rising water level and conditions favourable to Cladocera development during this cold interval; (2) the cladoceran assemblages differ from those at other sites in Europe; and (3) it is also possible that this time-span was divided into two parts. If the changes date from the Oldest Dryas, then this indeed would constitute the richest record of Cladocera in Poland, and probably in Europe, because the Oldest Dryas contains only 'arctic' taxa at other sites in Poland (Szeroczyńska, 1998a, 2006) and Europe (Ammann et al., 1985). On the other hand, changes in the aquatic ecosystem (an increase in the number of individuals, especially Bosminidae) show evidence of a rising water table and probably also of continued slight warming. This situation can be attributed to the increased intensity of permafrost melting. It thus seems that the Oldest Dryas was divided into two parts, an older part characterized by cooling, and a younger part that was slightly warmer and more humid (rising water level). The presence of these two parts is consistent with the patterns (lower values) of DCA axis 2 and DCA axis 1 (Fig. 4; see zone Z 7), and also separates the branches of the dendrogram (CONISS; Fig. 2; see the dendrogram in zone Z 7), which suggests that there is little similarity between the two parts. Probably the Oldest Dryas cooling was not so severe as commonly thought, but rather variable in terms of humidity and temperature. The high biodiversity of the Cladocera fauna in the lake may be related to its location in a warmer region of Poland, where the climate was influenced by warmer, wetter oceanic air masses, diminishing the overall severity of the weather. There is, however, no evidence as yet to support this hypothesis. The chiromomid data set from Żabieniec suggests that the temperature during the Oldest Dryas was generally considered to have been lower than in the Bølling-Allerød Interstadial (Płóciennik et al., 2011). Yet the small discrepancies between the Cladocera and chironomid data (which also occur in the second part of the Bølling) might be result of the fact that the chironomid data-set perhaps does not provide reliable estimates of the temperature optima of species. The reason for this might be that one of the calibration functions (e.g., Norwegian data) may underestimate of the highest temperatures, or that the temperature optimum of a particular taxon may be different in different calibration sets (Płóciennik et al., 2011). The local parameters (e.g., water level, acidity, lake size, or larval growth of chironomids-which depends on cumulative degree-days), might also be crucial factors determining chironomid assemblages (Płóciennik et al., 2011).
Despite this, cladoceran and chironomid reconstructions, give broadly similar results. And ultimately, it is also possible that the Oldest Dryas was shorter than suggested by the age-depth models which were constructed on the basis of the few radiocarbon dates from this timespan, and which show only approximate ages. If more radiocarbon dates were to become available, the age range of the Older Dryas could be established with more precision.

\section{CONCLUSIONS}

The Żabieniec profile shows significant changes in the Cladocera assemblages, including intense colonisation during the late Plenivistulian and Late Glacial. The cladocerans appear to be very useful in reconstructing the climate changes for the Older Dryas, Allerød, and Younger Dryas, and particularly for the time-span between the Younger Dryas and Preboreal (Holocene). Short-term climate oscillations are also recognized. A multivariate statistical technique (DCA) confirms the interpretations. In some cases, however, the Cladocera record shows slight discrepancies regarding the age that is established on the basis of an age-depth model. Some of these discrepancies may result from the lack of precise age determinations for samples from specific depths (the age-depth model is only a stratigraphic scheme).

Most interesting is the frequency of Cladocera at the early stage of the lake, during the late Plenivistulian. The changes that then took place leave some room for discussion; some of them might be correlated with locally prevailing conditions related to the initial stage of lake formation. The high frequency of cladocerans and the presence of cladoceran taxa preferring warmer water before approximately $16 \mathrm{ka}$ BP suggest favourable conditions (probably as a response to locally prevailing conditions). In the Oldest Dryas, the lake contained the highest frequency of cladocerans known in Poland. This phenomenon requires further study, as the period is little known. However, the results presented here represent the first attempt to construct a Plenivistulian record based on the analysis of Cladocera remains in Central Europe.

The composition during the Bølling is very interesting, since it indicates a mild, warm climate, whereas later taxa indicate shallower water or a slightly cooler or less humid climate. It is possible that this second phase represents the Intra-Bølling Cold Oscillation, but the Cladocera record shows some slight discrepancies. The cladoceran compositions of the youngest part of the Żabieniec profile, from the Older Dryas to the Younger Dryas, are similar to those reported from other sites in Europe. It is possible that the high cladoceran biodiversity found in Żabieniec was a consequence of its location in a warmer region of Poland, where the climate was characterized by the influence of warmer, wetter oceanic air masses, diminishing the effect of the overall unfavourable weather. 


\section{ACKNOWLEDGEMENTS}

I am indebted to Professor Tom van Loon from the Institute of Geology, A. Mickiewicz University, for his critical reading, several important suggestions and linguistic corrections. I am grateful to two reviewers for critical and helpful comments. The study was supported by a grant from the Polish Ministry of Science and Higher Education, No. 2P04E02228, "Changes in the Environment of the Łódź Hills (Wzniesienia Łódzkie) during the Vistulian (Weichselian) and Holocene in the light of interdisciplinary palaeoecological research of the Żabieniec swamp".

\section{REFERENCES}

Akima H, 1970. A new method of interpolation and smooth curve fitting based on local procedures. Journal of the Association for Computing Machinery 17(4): 589-602, DOI 10.1145/321607.321609.

Ammann B, Oeschger H, Andree A, Moedl M, Rieden T, Siegenthaler U, Tobolski K, Bonani B, Morenzoni E, Nessi M, Suter M, Wolffi W, Zullig H, Chaix L, Hofmann W, Elias SA, Wilkinson B and Eicher U, 1985. Lobsigensee-Late Glacial and Holocene environments of the lake on the Central Swiss Plateau. Dissertationes Botanicae 87: 127-170.

Balwierz Z, Forysiak J, Kittel P, Kloss M, Lamentowicz M, Pawłowski D, Twardy J and Żurek S, 2009. Zapis wpływów antropogenicznych w osadach torfowiska Żabieniec na tle jego rozwoju w holocenie. (Record of human impact in the Żabieniec peatland and its development in the Holocene) In: Domańska L, Kittel P, Forysiak J, eds., Środowiskowe uwarunkowania lokalizacji osadnictwa (Environmental determinants of settlement location) Vol. 2. Bogucki Wydawnictwo Naukowe, Poznań: 329-345. (in Polish).

Bennike O, Sarmaja-Korjonen K and Seppänen A, 2004. Reinvestigation of the classic late-glacial Bølling Sø sequence, Denmark: chronology, macrofossils, Cladocera and chydorid ephippia. Journal of Quaternary Science 19(5): 465-478, DOI 10.1002/jqs.852.

Birks HH and Birks HJB, 1980. Quaternary palaeoecology. The Blackburn Press, New York: 95-120.

Björck S, Walker M, Cwynar L, Johnsen S, Knudsen KL, Lowe J and Wohlfarth B, 1998. An event stratigraphy for the Last Termination in the North Atlantic region based on the Greenland ice-core record: a proposal by the INTIMATE group. Journal of Quaternary Science 13(4): 283-292, DOI 10.1002/(SICI)10991417(199807/08)13:4<283::AID-JQS386>3.0.CO $2-A$.

Bohncke SJP, Bos JAA, Engels S, Heiri O and Kasse C, 2008. Rapid climatic events as recorded in Middle Weichselian thermokarst lake sediments. Quaternary Science Reviews 27(1-2): 162-174, DOI 10.1016/j.quascirev.2007.09.017.

Bos JAA, Bohncke SJP, Kasse C and Vandenberghe J, 2001. Vegetation and climate during the Weichselian Early Glacial and Pleniglacial in the Niederlausitz, eastern Germany-macrofossil and pollen evidence. Journal of Quaternary Science 16(3): 269-289, DOI $10.1002 /$ jqs. 606

Bos JAA, Dickson JH, Coope GR and Jardine WG, 2004. Flora, fauna and climate of Scotland during the Weichselian Middle Pleniglacial - palynological, macrofossil and coleopteran investigations. Palaeogeography, Palaeoclimatology, Palaeoecology 204(1-2): 65-100, DOI 10.1016/S0031-0182(03)00724-7.

Bronk Ramsey C, 2009. Bayesian analysis of radiocarbon dates. Radiocarbon 51: 337-360.

De Costa JJ, 1964. Latitudinal distribution of chydorid Cladocera in the Mississippi valley, based on their remains in surficial lake sediments. Investigation of Indiana Lakes and Streams 6: 65-101.

Duigan CA and Birks HH, 2000. The late-glacial and early-Holocene palaeoecology of cladoceran microfossil assemblages at Kra- kenes, western Norway with a quantitative reconstruction of temperature changes. Journal of Paleolimnology 23(1): 67-76, DOI 10.1023/A:1008004513301.

Engels S, Bohncke SJP, Bos JAA, Heiri O, Vandenberghe $\mathrm{J}$ and Wallinga J, 2008. Environmental inferences and chironomid-based temperature reconstructions from fragmentary records of the Weichselian Early Glacial and Pleniglacial periods in the Niederlausitz area (eastern Germany). Palaeogeography, Palaeoclimatology, Palaeoecology 260(3-4): 405-416, DOI 10.1016/j.palaeo.2007.12.005.

Flössner D, 1972. Branchiopoda, Branchiura. Die Tierwelt Deutschlands 60: 1-501.

Frey DG, 1986. Cladocera analysis. In: Berglund BE, ed, Handbook of Holocene paleoecology and paleohydrology, John Wiley and Sons: 667-692.

Gasiorowski M and Kupryjanowicz M, 2009. Lake-peat bog transformation recorded in the sediments of the Stare Biele mire (Northeastern Poland). Hydrobiologia 631(1): 143-154, DOI 10.1007/s10750-009-9807-8.

Gliwicz Z, Slusarczyk MA and Slusarczyk M, 2001. Life history synchronization in a long-lifespan single-cohort Daphnia population in a fishless alpine lake. Oecologia 128: 368-378.

Goslar T, Ralska-Jasiewiczowa M, Starkel L, Demske D, Kuc T, Łącka B, Szeroczyńska K, Wicik B and Więckowski K, 1998. Discussion of the Late-Glacial record in the Lake Gościąż sediments. In: Ralska-Jasiewiczowa M, Goslar T, Madeyska T and Starkel L, eds., Lake Gościąż, Central Poland. A monographic study: 171180.

Goulden CE, 1964. The history of the cladoceran fauna of Esthwaite Water (England) and its limnological significance. Archiv für $\mathrm{Hy}$ drobiologie 60: 1-52.

Grimm EC, 1987. CONISS: a Fortran 77 program for stratigraphically constrained cluster analysis by the method of incremental sum of squares. Computers \& Geosciences 13(1): 13-35, DOI 10.1016/0098-3004(87)90022-7.

Harmsworth RV, 1968. The developmental history of Belham Tarn (England) as shown by animal microfossils, with special reference to the Cladocera. Ecological Monographs 38(3): 223-241, DOI $10.2307 / 1942429$.

Hill MO and Gauch HG, 1980. Detrended correspondence analysis, an improved ordination technique. Vegetatio 42(1-3): 47-58, DOI 10.1007/BF00048870.

Hofmann W, 1978. Analysis of animal microfossils from the Großer Segeberger See (F.R.G.). Archiv für Hydrobiologie 82: 316-346.

Hofmann W, 1986. Developmental history of the Grosser Plöner See and the Schonsee (North Germany): cladoceran analysis, with special references to eutrophisation. Archiv für Hydrobiologie Suppl. 74: 259-287.

Hofmann W, 1993. Dynamics of littoral cladocera assemblage under the influence of climatic and water depth changes from Alleröd to Subboreal. Verhandlungen der Internationalen Vereinigung für Limnologie 25: 1095-1101.

Hofmann W, 2000. Response of the chydorid faunas to rapid climatic changes in four alpine lakes at different altitudes. Palaeogeography, Palaeoclimatology Palaeoecology 159(3-4): 281-292, DOI 10.1016/S0031-0182(00)00090-0.

Huber K, Weckström K, Drescher-Schneider R, Knoll J, Schmidt J and Schmidt R, 2010. Climate changes during the last glacial termination inferred from diatom-based temperatures and pollen in a sediment core from Längsee (Austria). Journal of Paleolimnology 43(1): 131-147, DOI 10.1007/s10933-009-9322-y.

Huijzer B and Vandenberghe J, 1998. Climatic reconstruction of the Weichselian Pleniglacial in northwestern and central Europe. Journal of Quaternary Science 13(5): 391-417, DOI 10.1002/(SICI)1099-1417(1998090)13:5<391::AIDJQS397>3.0.CO;2-6.

Kamenik C, Szeroczyńska K and Schmidt R, 2007. Relationships among recent Alpine Cladocera remains and their environment implications for climate-change studies. Hydrobiologia 594(1): 3346, DOI 10.1007/s10750-007-9083-4. 
Keller AA, Oviatt CA, Walker HA and Hawk JD, 1999. Predicted impacts of elevated temperature on the magnitude of the winterspring phytoplankton bloom in temperate coastal waters: a mesocosm study. Limnology and Oceanography 44(2): 344-356, DOI 10.4319/10.1999.44.2.0344.

Kłysik K, 2001. Warunki klimatyczne (Climatic conditions). In: Liszewski S, ed, Zarys monografii województwa łódzkiego (Monograph of the Łódź Voivodeship). Łódzkie Towarzystwo Naukowe, Łódź (in Polish).

Koç Karpuz N and Jansen E, 1992. A high-resolution diatom record of the last deglaciation from the SE Norwegian Sea: documentation of rapid climate changes. Paleoceanography 7(4): 499-520, DOI 10.1029/92PA01651.

Kolstrup E, 1980. Climate and stratigraphy in northwestern Europe between $30,000 \mathrm{BP}$ and $13,000 \mathrm{BP}$, with special reference to The Netherlands. Mededlingen Rijks Geologische Dienst 32:181-253.

Korhola A, 1999. Distribution patterns of Cladocera in subarctic Fennoscandian lakes and their potential in environmental reconstruction. Ecography 22(4): 357-373, DOI 10.1111/j.16000587.1999.tb00573.x.

Korhola A and Rautio M, 2001. Cladocera and other branchiopod crustaceans. In: Smol JP, Birks HJB and Last WM, eds, Tracking Environmental Change Using Lake Sediments, Zoological Indicators. Kluwer Academic Publishers, Dordrecht 4: 5-41.

Kulesza P, Suchora M, Pidek IA and Alexandrowicz WP, 2011. Chronology and directions of Late Glacial paleoenvironmental changes: A multi-proxy study on sediments of Lake Słone (SE Poland). Quaternary International 238(1-2): 89-106, DOI 10.1016/j.quaint.2010.12.024.

Lamentowicz M, Balwierz Z, Forysiak J, Płóciennik M, Kittel P, Kloss M, Twardy J, Żurek S and Pawlyta J, 2009. Multiproxy study of anthropogenic and climatic changes in the last two millennia from a small mire in central Poland. Hydrobiologia 631(1): 213-230, DOI 10.1007/s10750-009-9812-y.

Litt T, Brauer A, Goslar T, Merkt J, Balaga K, Müller H, RalskaJasiewiczowa M, Stebich M and Negendank JFW, 2001. Correlation and synchronisation of Lateglacial continental sequences in northern central Europe based on annually laminated lacustrine sediments. Quaternary Science Reviews 20(11): 1233-1249, DOI 10.1016/S0277-3791(00)00149-9.

Lowe JJ, Rasmussen SO, Björck S, Hoek WZ, Steffensen JP, Walker MJC, Yu ZC, and the INTIMATE group, 2008. Synchronization of palaeoenvironmental events in the North Atlantic region during the Last Termination: a revised protocol recommended by the INTIMATE group. Quaternary Science Reviews 27(1-2): 6-17, DOI 10.1016/j.quascirev.2007.09.016.

Lotter AF, Eicher U, Birks HJB and Siegenthaler U, 1992. Late Glacial climatic oscillations as recorded in Swiss lake sediments. Journal of Quaternary Science 7: 187-204, DOI 10.1002/jqs.3390070302.

Lotter AF, Birks HJB, Eicher U, Hofmann W and Marchetto A, 1997. Modern diatom, Cladocera, chironomid, and chrysophyte cyst assemblages as quantitative indicators for the reconstruction of past environmental conditions in the Alps. I. Climate. Journal of Paleolimnology 18(4): 395-420, DOI 10.1023/A:1007982008956.

Lotter AF, Birks HJB, Eicher U, Hofmann W, Schwander J and Wick L, 2000. Younger Dryas and Alleröd summer temperatures at Gerzensee (Switzerland) inferred from fossil pollen and cladoceran assemblages. Palaeogeography, Palaeoclimatology, Palaeoecology 159(3-4): 349-361, DOI 10.1016/S0031-0182(00)00093-6.

Manikowska B, 1995. Aeolian activity differentiation in the area of Poland during the period 20-8 ka BP. Biuletyn Peryglacjalny 34: 127-165.

Marks L, 1996. Rola martwego lodu w kształtowaniu mis jeziornych obecnych pojezierzy (The role of dead-ice in shaping present-day lake basins). Acta Geographica Lodziensis 74: 181-192 (in Polish).

Meijering MPD, 1983. On the occurrence of 'arctic' Cladocera with special reference to those along the Strait of Belle Isle (Quebec, Labrador, Newfoundland). Internationale Revue der gesamten $\mathrm{Hy}$ drobiologie 68: 885-893.
Mojski JE, 2005. Ziemie polskie w czwartorzędzie. Zarys monograficzny (Poland in Quaternary period. Monograph) PIG, Warszawa (in Polish).

Patalas K, 1990. Diversity of the zooplankton communities in Canadian lakes as a function of climate. Verhandlungen der Internationalen Vereinigung für Limnologie 24: 360-368.

Płóciennik M, Self A, Birks HJB and Brooks SJ, 2011. Chironomidae (Insecta: Diptera) succession in Żabieniec bog and its palaeo-lake (central Poland) through the Late Weichselian and Holocene. Palaeogeography, Palaeoclimatology, Palaeoecology 307(1-4): 150167, DOI 10.1016/j.palaeo.2011.05.010.

Poulsen EM, 1928. Faunistische und biologische Unterschungen über die Cladocerafauna von Danmark (Zoological and biological investigations of the Cladocera fauna of Denmark). Videnskabeliege Meddelelser Fra Dansk Naturhistorik Forening 86: 203-242 (in German).

Ralska-Jasiewiczowa M, Demske D and Van Geel B, 1998. LateGlacial vegetation history recorded in the Lake Gościąż sediments. In: Ralska-Jasiewiczowa M, Goslar T, Madeyska T and Starkel L, eds, Lake Gościaż, Central Poland. A monographic study: 128143

Rasmussen SO, Andersen KK, Svensson AM, Steffensen JP, Vinther BM, Clausen HB, Siggaard-Andersen M-L, Johnsen SJ, Larsen LB, Dahl-Jensen D, Bigler M, Röthlisberger R, Fischer H, GotoAzuma K, Hansson ME and Ruth U, 2006. A new Greenland ice core chronology for the last glacial termination. Journal of Geophysical Research 111: D06102, DOI 10.1029/2005JD006079.

Reimer PJ, Baillie MGL, Bard E, Bayliss A, Beck J W, Blackwell PG, Bronk Ramsay C, Buck CE, Burr GS, Edwards RL, Friedrich M, Grootes PM, Guilderson TP, Hajdas I, Heaton TJ, Hogg AG, Hughen KA, Kaiser KF, Kromer B, McCormac G, Manning S, Reimer RW, Richards DA, Southon JR, Talamo S, Turney CSM, van der Plicht $J$ and Weyhenmeyer C, 2009. IntCal09 and Marine09 radiocarbon age calibration curves, $0-50000$ years cal BP. Radiocarbon 51(4): 1111-1150.

Røen U, 1995. Krebsdyr V. Danmarks Fauna 85 (Crustaceans of Denmark). Dansk Naturhistorisk Forening, Copenhagen, 358 (in Danish).

Rotnicki K and Borówka RK, 1995. Dating of the Upper Pleni-Vistulian Scandinavian Ice Sheet in the Polish Baltic Middle Coast. In: Mojski JE, ed., Proceedings of the Third Marine Geological Conference ,, The Baltic”. Polish Geological Institute Special Papers 149: 84-89.

Sarmaja-Korjonen K, Szeroczyńska K and Gasiorowski M, 2003. Subfosil Chydorid taxa and assemblages from lake sediments in Poland and Finland with special reference to climate. Studia Quaternaria 20: 25-34.

Sarmaja-Korjonen K, Nyman M, Kultti S and Väliranta M, 2006. Palaeolimnological development of Lake Njargajavri, northern Finnish Lapland, in a changing Holocene climate and environment. Journal of Palaeolimnology 35(1): 65-81, DOI 10.1007/s10933-0057337-6.

Schmidt R, Wunsam S, Brosch U, Fott J, Lami A, Löffler H, Marchetto A, Müller H, Pržakova M and Schwaighofer B, 1998. Late and post-glacial history of meromictic Langsee (Austria) in respect to climate change and anthropogenic impact. Aquatic Science 60(1): 56-88, DOI 10.1007/PL00001313.

Szeroczyńska K, 1985. Cladocera jako wskaźnik ekologiczny w późnoczwartorzędowych osadach jeziornych Polski Północnej. (Cladocera as a source of information in studies of lake sediments in northern Poland). Acta Paleontologica Polonica 30: 3-69 (in Polish).

Szeroczyńska K, 1998a. Cladocera analysis in the Late-Glacial sediments of the Lake Gościąż. In: Ralska-Jasiewiczowa M, Goslar T, Madeyska T and Starkel L, eds., Lake Gościąż, Central Poland. A monographic study: 148-158.

Szeroczyńska K, 1998b. Wioślarki (Cladocera, Crustacea) jako źródło informacji w badaniach osadów jeziornych. (Cladocerans (Cladocera, Crustacea) as a reference in lake sediment studies. Studia Geologica Polonica 112: 9-28 (in Polish). 
Szeroczyńska K, 2003. Cladoceran succession in lakes and peat bogs of Łęczna-Włodawa Lake District. Limnological Review 3: 235-242.

Szeroczyńska K, 2006. The significance of subfossil Cladocera in stratigraphy of Late Glacial and Holocene. Studia Quaternaria 23: $37-45$.

Szeroczyńska K and Sarmaja-Korjonen K, 2007. Atlas of subfossil Cladocera from Central and Northern Europe. Friends of Lower Vistula Society, Swiecie: $87 \mathrm{pp}$.

Ter Braak CJF and Šmilauer P, 2002. CANOCO Reference Manual and CanoDraw for Windows User's Guide: Software for Canonical Community Ordination (version 4.5). Ithaca, NY, USA: Microcomputer Power.
Twardy J, Żurek S and Forysiak J, 2010. Torfowisko Żabieniec: warunki naturalne, rozwój i zapis zmian paleoekologicznych w jego osadach (Żabieniec peatland: natural conditions, development and paleoecological record in their sediments). Bogucki Wydawnictwo Naukowe, Poznań: 214 pp (in Polish).

Walanus A and Nalepka D, 1999. Polpal program for counting pollen grains, diagrams plotting and numerical analysis. Acta Palaeobotanica, Supplementum 2: 659-661.

Whiteside MC, 1970. Danish chydorid Cladocera: modern ecology and core studies. Ecological Monographs 40(1): 79-118, DOI 10.2307/1942442.

Woś A, 1999. Klimat Polski (Climate of Poland). Wydawnictwo Naukowe PWN, Warszawa: 302 pp (in Polish). 